\title{
Which New Small and Medium Enterprises in South Africa Have
}

\section{Access to Bank Credit?}

\author{
OLAWALE FATOKI \\ Department of Business Management, University of Fort Hare \\ X1314, Eastern Cape, 5200, South Africa \\ Tel: 927-40-653-2248Ｅ-mail: ofatoki@ufh.ac.za \\ AKINWUMI ODEYEMI \\ Department of Statistics, University of Fort Hare \\ X1314, Eastern Cape, 5200, South Africa \\ Tel: 927-40-653-2447 E-mail: aodeyemi@ufh.ac.za
}

\begin{abstract}
New SMEs are very important to the economy of South Africa. Their failure rate at about $75 \%$ is one the highest in the world. Lack of finance is one of the primary reasons for the failure of new SMEs in South Africa. About $75 \%$ of all applications for bank credit by new SMEs are rejected. This objective of the paper was to investigate the determinants of credit approval for new SMEs. The survey method and self-administered questionnaires were used for data collection. 445 respondents took part in the survey. Data was analysed by logistic regression. The results indicate that managerial competencies, business information, networking, location, crime, business size and incorporation are significant determinants of credit approval.
\end{abstract}

Keywords: New SMEs, Commercial banks, Debt, Logistic regression

\section{Introduction}

Small and medium enterprises (SMEs) are increasingly seen as playing an important role in the economies of many countries. Thus, governments throughout the world focus on the development of the SME sector to promote economic growth. In South Africa, SMEs contribute $56 \%$ of private sector employment and $36 \%$ of the gross domestic product (Ntsika Enterprise Promotion Agency, 2002). South Africa suffers from high unemployment with an official estimate of approximately $24.5 \%$ of the economically active population unemployed (Statistics South Africa, 2009). One of the best ways to address unemployment is to leverage the employment creation potential of small businesses and to promote small business development (FinMark Trust, 2006).

Gree \& Thurnik (2003) argue that the contribution of the SME sector cannot be sustained without the creation and sustenance of new SMEs. According to Maas and Herrington (2006) a new SME in South Africa can be described as an SME that has been in existence for less than forty two months. Wong et al. (2005) point out that Schumpeter in 1934 was one of the earliest economists to argue for new firm creation. According to Schumpeter, new firms are the vital force behind the progress of capitalism. The innovative activity of entrepreneurs feeds a creative "destruction process" by causing constant disturbances to an economic system in equilibrium, creating opportunities for economic rent. According to Maas \& Herrington (2006) new SMEs are seen as a significant component of the solution to South Africa's development issues which include poverty, income inequality and unemployment. However, the creation rate of new SMEs in South Africa as measured by the total early-stage entrepreneurial activity is one of the lowest in the world (Herrington et al. 2009). In addition, $75 \%$ of new SMEs created in South Africa fail within the first two years of operation. The probability of a new SME surviving beyond 42 months and becoming an established firm is less likely in South Africa than in any other GEM participating country (Von Broembsen et al 2005). Various challenges and impediments prevent the creation of new SMEs and as well cause the high failure rates of new SMEs in South Africa. One of these is the non availability of formal sector financing.

According to Demirguc-Kunt et al (2006) the two primary sources of external finance for new SMEs are equity and debt. External equity in the form of venture capital or the stock exchange is usually not available for new SMEs. Venture capitalists often enter the firm at the middle or later stages of its life cycle. According to the 
South African Venture Capital Association (2008) there are at least 65 venture capital funds in South Africa controlling a total of R29 billion with an average investment size of R15.4 million. However, investment with SME focus is approximately R1.1 billion which is only $3.8 \%$ of the funds. This indicates that the availability of venture capital is limited for new SMEs in South Africa. The lack of venture capital funds makes many new SMEs dependent on bank loans and overdrafts and suppliers credit for early-stage financing. Despite the dependence of SMEs on debt finance, paradoxically access to debt finance is very limited for new SMEs especially in developing countries. Commercial banks hesitate to lend to new SMEs. FinMark Trust (2006) provides evidence that only $2 \%$ of new SMEs in South Africa are able to access bank loans. In addition, Foxcroft et al. (2002) report that $75 \%$ of applications for bank credit by new SMEs in South Africa is rejected. Stiglitz \& Weiss (1981) refer to this phenomenon as capital rationing. The question is "what are the determinants of access to debt from commercial banks by new SMEs in South Africa?" Understanding the features of new SMEs that are able to access bank credit is significant to improving the approval rate of their credit applications. Improving access to finance is one of the ways to increase the creation rate and reduce the failure rate of new SMEs in South Africa.

The National Small Business Act of South Africa of 1996, as amended in 2003, describes an SME as a separate and distinct entity including cooperative enterprises and non-governmental organisations managed by one owner or more, including its branches or subsidiaries if any is predominantly carried out in any sector or sub-sector of the economy mentioned in the schedule of size standards (refer to Table 1) and can be classified as an SME by satisfying the criteria mentioned in the schedule of size standards (Government Gazette of the Republic of South Africa, 2003). Table 1 depicts the Schedule of size standards for the quantitative definition of SMEs in South Africa.

Table 1 here

\section{Research Objectives}

The objective of the study is to empirically investigate the determinants of access to bank credit by new SMEs in South Africa.

\section{Literature review}

\subsection{Theoretical foundation}

According to Sogorb Mira (2002) the most relevant capital structure theories that explain the capital structure of SMEs are those related to static trade-off, adverse selection and moral hazard (agency theory) and the pecking order theory. Andree \& Kallberg (2008) point out that the genesis of modern capital structure theory lies in the work of Modigliani and Miller (1958) in their famous proposition I - often referred to as the "irrelevance theorem". The theorem suggests that, as an implication of equilibrium in perfect capital markets, the choice of capital structure does not affect a firm's market value. Modigliani \& Miller (1958) based their irrelevance theorem on certain perfect market assumptions. These assumptions include no corporate taxes, no brokerage or floatation cost for securities, and symmetrical information. The initial perfect market assumptions, on which the 1958 theory of Modigliani \& Miller was based, were later reviewed in 1963 with the introduction of the tax benefits of debt. This is attributed to the fact that a perfect market does not exist in the real world. Since interest on debt is tax-deductible, thereby creating tax savings for the borrower, it becomes possible for firms to minimize their costs of capital and maximize shareholders' wealth by using debt. This is known as the leverage effect of debt (Modigliani \& Miller, 1963).

According to Miller \& Modigliani (1963) a firm should have $100 \%$ debt in its capital structure. This way the firm can take absolute advantage of the tax-shield. Scott (1972) and Kraus \& Litzenberger (1973) point out that theoretically $100 \%$ tax shield does not exist in reality because of distress costs. Debt leads to a legal obligation to pay interests and principal. If a firm cannot meet its debt obligations it is forced into bankruptcy and incurs associated costs. Sogorb Mira (2002) and Andree \& Kallberg (2008) find that the fiscal advantage of debt cannot be applied in the new SME context because new SMEs are less likely to be profitable and therefore may not be able to use debt in order to get tax shields. In addition, Daniel et al (2006) point out that in the case of new SMEs the expected costs of bankruptcy is quite high and the expected costs of financial distress may outweigh any potential benefits from the tax shield. However, new SMEs also have limited access to external equity capital such as venture capital and the stock market. This implies that new SMEs will have to rely only on internal equity which is often inadequate as a source of capital. The limitations of static trade off theory suggest the reliance on internal equity by new SMEs. Yet, the reality for growing new SMEs is a reliance on debt and external equity because of the inadequacy of internal equity (Frelinghaus et al 2005). 
According to Stiglitz \& Weiss (1981) agency problems such as asymmetric information and moral hazards can impact on the availability of credit and hence the capital structure of new SMEs. Stiglitz \& Weiss termed this phenomenon credit rationing. The core of the argument is that suppliers of finance may choose (due to asymmetric information, adverse credit selection and monitoring problems) to offer an array of interest rates that would leave a significant number of potential borrowers without access to credit. The Stiglitz \& Weiss' theory therefore suggests that there are significant numbers of SMEs that could use funds productively if they were available, but cannot obtain finance from the formal financial system. The agency cost argument suggests a pattern of relationship for the capital structure of new SMEs. The pattern of the relationship pattern is low-high-high. This implies low amount debt at the beginning, high debt as the firm develops and low debt at prime when the firm would have accumulated some retained earnings. In terms of agency cost theory, new SMEs are expected to have the least debt and thus depend on internal equity and that debt levels will gradually increase as the firm develops and becomes established. Frelinghaus et al. (2005) disagree with the pattern of relationship suggested by the agency theory. The authors argue that whilst it is true that firms in latter stages do, in fact, have more debt than firms in prime, agency theory cannot explain why firms in the early stages of development have more debt than firms in prime. According to Myers (1984) the pecking order theory suggests that there is no well-defined optimal capital structure, instead the debt ratio is the result of hierarchical financing over time. Management has a preference to choose internal financing before external financing. When a firm is forced to use external financing sources, debt issuance is preferred to new equity. Conclusively, the three theories suggest the importance of debt as a financing source to new SMEs. Rungani (2008) points out that a key consideration in choosing the source of finance for a new SME is to strike a balance between equity and debt to ensure that the funding structure suits the business. Martinovic (2008) agrees that it is important to examine the needs of the business and the timeline for reaching certain financial goals in order to determine the appropriate capital structure for a business. Cassar (2004) agrees that the logic seems clear, when small business starts, current assets should be financed with a source of funds long enough to allow the firm to reach cash flow breakeven in an orderly manner. Kortschak (2007) argues that when used in the right amounts and for the right purposes, leverage or debt financing can be a critical part of a firm's growth. The challenge lies in determining the prudent amount of debt a new SME can take on without jeopardizing its well-being and long-term growth potential.

\subsection{Empirical review}

\subsubsection{Determinants of access to debt}

\subsubsection{Managerial competencies}

Managerial competencies are sets of knowledge, skills, behaviors and attitudes that contribute to personal effectiveness (Hellriegel et al. 2008). Martin \& Staines (2008) examine the importance of management competence in small firm success. They find lack of managerial experience, skills and personal qualities as well as other factors such as adverse economic conditions, poorly thought out business plans and resource starvation are found as the main reasons why new firms fail. The distinguishing feature of high growth and low growth small firms is the education, training and experience of managers. Lyles et al. (2004) find that managerial competencies as measured by the education of the founder, managerial experience, entrepreneurial experience, start-up experience and functional area experience positively impact on new venture performance. Other empirical studies such as Smallbone \& Welter (2001) and Hisrich \& Drnovsek (2002) find that managerial competencies as measured by education, managerial experience, start-up experience and knowledge of the industry positively impact on the performance of new SMEs. In South Africa, Herrington \& Wood (2003) point out that lack of education and training has reduced management capacity in SMEs in South Africa and one of the reasons for their high failure rates. This suggests that managerial competency will impact on access to finance by new SMEs.

\subsubsection{Collateral}

Gitman (2003) defines collateral as assets that are pledged by a borrower to a lender as security for the payment of debt. Barbosa and Moraes (2004) argue that firms that invest heavily in tangible assets tend to have higher financial leverage since they can borrow at lower interest rates if their debt is secured with such assets. According to Coco (2000) collateral can solve problems derived from asymmetries in valuation of projects, uncertainty about the quality of projects and the riskiness of borrowers, and problems related to the cost of monitoring or supervising borrowers' behavior. Collateral requirements also reduce moral hazard problems. Collateral requirements can reduce moral hazard problems by adding a potential cost to borrowers if they do not make their best effort. The borrower may be willing to divert funds towards private use or extract the whole surplus from the project. When collateral requirements are in place this perverse incentive is diminished, since 
that sort of action would increase the chance of losing the assets pledged as collateral (Barbosa \& Moraes, 2004). This suggests that the availability of collateral will impact on access to debt finance to new SMEs.

\subsubsection{Business information}

Pretorius \& Shaw (2004) point out that financial information is one of the primary measures of the capacity of a business to effect repayment of credit. Financial information and business information are usually contained in the business plan of the new SME. According to a good business plan is perceived as one of the most essential documents to be prepared by the entrepreneur or small venture owner when setting up a business. Entrepreneurs and small business owners are encouraged to prepare a business plan for presentation to banks, financial institutions and venture capitalists to stand a chance of obtaining financial support. Kitindi et al (2007) find that creditors, banks and other lenders use financial information provided by firms to analyse their present performance and predict future performance. The researchers find that annual financial statements and audit reports are required by formal lenders in Botswana. Information from the financial statements together with other information obtained through discussions with prospective borrowers is the main sources of information to lenders. Information obtained from the financial statements acts as indicator of borrower's future prospects and ability to service a loan. Therefore banks and other creditors prefer, demand and use financial information.

\subsubsection{Networking}

Coulthard \& Loos (2007) describe networking in a small firm context as an activity in which entrepreneurially oriented SME owners build and manage personal relationships with particular individuals in their surroundings. Shane and Cable (2002) agree that networking can be used to reduce information asymmetry in creditor/debtor relationships. Social obligations between connected parties, and information transfer through social relationships, influence venture finance decisions. Owualah (2002) find that long-standing relationship between a bank and new SME owner does convey any advantage in the case of bank loans. In addition, networks and relationships increase a firm's legitimacy, which in turn positively influences the firm's access to external financing. Networks also help a firm learn appropriate behavior and therefore obtain needed support from key stakeholders and the general public. In large part, networking substitutes for the lack of effective market institutions, and can be an effective way for SMEs to access external financing, including bank loans in emerging economies. Networking could be expected to provide to the banks information on legitimacy, which in turn should give the SMEs advantages in accessing commercial bank loans (Ngoc et al, 2009).

\subsubsection{Location}

Dahl \& Sorenson (2007) note that location also impacts on the market potential and growth opportunities of new firms. Geographical proximity to either critical buyers or suppliers produces a form of enhanced environmental scanning that enables new firms to more easily identify and exploit growth opportunities in the market. Gilbert (2008) points out that the geographical area where the firm is launched has implications for its access to markets and resources. Firms located in metropolitan areas may therefore have higher chance of success than those located in rural areas. The South African Presidency (2008) finds that crime is higher in rural areas compared to urban areas.

\section{Research methodology}

The empirical approach consists of primary research and collection of data through the use of questionnaires. Self-administered questionnaires were delivered to respondents who completed them and the interviewer collected them at an appointed time. The population of new SMEs in the three major towns of Eastern Cape South Africa (Port Elizabeth, East London and King Williams Town) was obtained from the Small Business Development Agency (SEDA) and Yellow Pages Telephone Directory. The population of new SMEs was 737. The minimum recommended sample size using Raosoft was 253. However, 600 questionnaires were distributed because of the limitations associated with self-administered questionnaires such as non-response and 445 returned after repeated visits and telephone calls to the respondents. Raosoft takes into consideration four factors in arriving at the sample size. These are the margin of error (5\% was used for the study), the confidence interval (95\% was used for the study), the population and the response distribution (usually 50\%) (Raosoft Sample Size Calculator, 2009). The response rate was $74.2 \%$. Data was collected between May and November, 2009. The Kolmogorov-Smirnov test was used to measure the normality of the data. The significance of the Kolmogorov-Smirnov test was greater than 0.05 in all the tests. This implies that the normality of the data can be assumed. According to Allison (2001) a missing value may represent or is a product of an unknown value. There were only four cases of missing values and pairwise deletion method under SPSS was used to treat the missing values. 


\section{Results and discussions}

Out of 445 respondents, 406 (91.2\%) have applied for credit from commercial banks. The results indicate that apart from owners' funds, commercial banks are the next major potential source of funds for new SMEs. The results are consistent with Reitan and Waago (2002) and Kauffman Foundation (2007) on the capital structure decisions of new SMEs that external debt financing such as bank loans are the more common sources of funding after internal equity for many new SMEs. Out of the 406 respondents that applied for credit from commercial banks, 112 respondents (27.6\% were successful (i.e. applications approved by commercial banks) and 294 (72.4\%) were unsuccessful (applications declined by commercial banks). This results are consistent with Stiglitz and Weiss (1981) and Coleman and Cohn (2002) that new SMEs are credit rationed. Table 2 depicts the determinants of approval of credit for new SMEs using logistic regression. The characteristics focused on by the study include (1) collateral (represented by the presence of property) (2) managerial competencies (represented by high education, business education, general working experience and related experience) (3) business information (represented by the existence of a business plan and whether the business plan was produced by an accountant/consultant) (4) networking (represented by membership of a professional association, and relationship with the bank) (5) location of the business (city 1, rural 0) and insurance. The dummy variables used were 1 if the answer is Yes and 0 if the answer is No. The impact of demographic variables were measured using gender, size, legal status, age of the owner, line of business and partner in business. Logistic regression was used to analyse the impact of variables such as collateral, managerial competency, networking, business information, location and demographic variables on the approval of credit. According to Freeman et al (2008) when reporting the results of a logistic regression analysis, the estimated odd ratios for the regression coefficients, their confidence intervals and associated P-values should be presented. In addition, it is necessary to give some information about the goodness of fit of the model to the data as measured by the Hosmer and Lemeshow test. The logistic regression results are presented in Table 2.

Table 2 here.

The results show that the Hosmer-Lemeshow statistics are not significant, indicating goodness-of-fit is at an acceptable level for in-sample predictive purposes.

The odd ratio for property is 7.04 with a p-value of 0.02 indicating that new SMEs with property that can serve as collateral are 7.04 more likely to be successful in their applications for credit compared to new SMEs without collateral. The results are consistent with other empirical studies on the importance of collateral to the availability of debt finance such as Coco (2000) and Barbosa and Moraes (2004). The results also indicate new SME managed by owners with high education (odd ratio 3.66, p-value 0.04) and related business experience (odd ratio 4.83, p-value 0.04) are more likely to be successful in their credit applications. The p-values for new SME owners with business education and working experience are higher than 0.05 indicating that they are not significantly more likely to have their credit applications successful. The results are consistent with Lyles et al (2004) and Marin and Staine (2008).

New SMEs that are able to produce business plan (odd ratio 6.62, p-value 0.01) are significantly more likely to be successful in their credit applications. The results for business plans produced by an accountant are not significant. The results are consistent with the findings of Pretorius and Shaw (2004) and Kitindi et al. (2007). With no previous relationship as the reference category, the results indicate that new SMEs owners that have previously relationships with a bank are significantly more likely to be successful in their credit applications. However, belonging to a professional trade association does not have any significant impact on the success of credit applications. The results are consistent with Shane and Cable (2002) and Ngoc et al. (2009).

Location (odd ratio 3.65, p-value 0.01 ) of the business appears to be a significant factor in the success of credit applications. New SMEs located in the city are significantly more likely to be successful in their credit applications compare to those located in the rural area consistent with Dahl and Sorenson (2007) Gilbert (2008) and the South African Presidency (2008) points out that the crime rate is significantly higher in the rural areas compared to urban areas in South Africa. New SMEs that are insured are also significantly more likely to be successful in their credit applications with an odd ratio of 5.24 and p-value of 0.04 . With reference to demographic variables, the gender, age of the owner of the business and industry are not significant factors in credit approval as indicated by their low odd ratios and insignificant p-values. This is consistent with other studies such as Blumberg and Letterie (2002) and Akarro (2009). The results indicate that the size of the firm and incorporation are significant factors in the success of credit applications. Medium sized firms are 3.79 times more likely to be success in their credit applications than small firms. In addition, incorporated firms are 4.25 more likely to be successful in their credit applications compared to unincorporated firms. The results are 
consistent with Bollingtoft et al (2003) and Barbosa and Moraes (2004).

\section{Conclusions and managerial implications}

The results indicate that collateral, managerial competency (especially high education and related experience), business plan, relationships with banks and the location of the business are important determinants of access to bank credit by new SMEs. In addition, incorporation and the size of the firm are also significant factors. In the light of these findings, the study recommends that to get debt funding from banks, it is necessary for the owner of a new SME to have either business or personal assets to be used as collateral. Therefore, to get the required funding from commercial banks, it is first about the owner of the new SME getting investment ready. Investors look out for very specific things when they assess requests for funding. Entrepreneurs must be made aware of the needs and concerns of particular types of investor. In addition, government and its agencies have, over the years, expended significant resources creating and implementing market interventions. It is vital that these interventions are effective and meet the needs of those they declare to support. It is therefore incumbent on Government and other stakeholders to ensure that these schemes, such as the Small Firm Loan Guarantee, are well publicised and available to new SMEs.

In addition, new SME owners must ensure that they have high education which implies education higher than Matric level in South Africa. Educational institutions should introduce and strengthen entrepreneurial education. When learners are oriented into entrepreneurship from an early age, it becomes easier to develop successful ventures. Peacock (2004) for instance points out that “.... a small business management course delivered to students and apprentices via the education system is the most effective way to provide basic management training".

To improve the related experience of new SME owners "learning from peers" or mentorship approach can be instituted by government agencies to help new SMEs. New SMEs should look at using non-executives at an early stage to bring external expertise and guide investment decisions. To improve networking it is important for new SME owners to open bank accounts before they commence business operations and maintain good relationships with banks. Good credit history must always be maintained. Agreements such as repayment of credit extended should always be met. In addition, entrepreneurs need to attend seminars and trade fairs and also join trade associations.

Owners of new SMEs have to take greater responsibility for their own learning. Therefore, they need to create a positive attitude towards entrepreneurship and training. The present system where government agencies such as the Small Enterprise Development Agency (SEDA) use consultants that write business plans for entrepreneurs which they cannot articulate does make sense, but could potentially be counterproductive. The personal involvement of the entrepreneur in gathering the relevant information and in the writing of the business plan is critical to learn about the industry and to the success of the new venture. Entrepreneurs also need to acquire business and financial management skills if they want to get the required funding from investors.

Location and crime are intertwined. The high crime rate in South Africa must be reduced to improve the availability of debt from commercial banks. The best way to reduce crime is to make the legal system more efficient (especially the speed of court judgments) so that criminals are promptly arrested and punished. Government should work in partnership with organisations such as Business Against Crime South Africa and Business Unity South Africa. The literature review showed that poverty is one of the causes of crime. There is the need to create work opportunities for the vast number of the unemployed in South Africa. There is also a need for a well-publicized educational campaign against crime. More effective policing is needed, including better police visibility, area coverage and faster response times. New SMEs should be encouraged to insure their businesses. Government can assist in subsidizing the cost of insurance. Government can also help to subsidize once-off security costs such as burglar proofing. Government agencies can also help to subsidise the incorporation cost of new SMEs.

\section{Limitations of the study and areas for further research}

The study focused only on bank credit. The determinants of other sources of credit to new SMEs such as trade credit and government were not investigated. In addition, the study focused on the demand side. Further study could investigate the determinants of credit approval from the supply side (i.e. banks)

\section{References}

Akarro, R.J. (2009). Some factors associated with decisions by the various banks on the issuance of loans to the small/medium entrepreneurs in Tanzania. International Research Journal of Finance and Economics, 28, 86-97.

Allison, P. D. (2001). Missing data. (4 $4^{\text {th }}$.ed.) Thousand Oaks. Sage Publications. 
Andree, C., \& Kallberg, C. (2008). The capital structure of SMEs: evidence from the Swedish security industry. [Online] Available: http://www.student.se/uppsok/search2.php?allasmes [Accessed: 17 August 2009].

Balkenhol, B. \& Evans-Klock, C. (2002). Private equity and capitalization of SMMEs in South Africa: Quo vadis? [Online] Available: http://www.ilo.org/public/english/employment/finance/download/wp.34.pdf [Accessed: 20 August 2008].

Barbosa, E.G., \& Moraes, C.C. (2004). Determinants of the firm's capital structure: The case of the very small enterprises. [Online] Available: http://econpa.wustl.edu.8089/eps/fin/papers 0302/0302001.pdf (August 18,2007)

Blumberg, B.F., \& Letterie, W.A. (2008). Business starters and credit rationing in small business. Small Business Economics, 3, 187-200.

Bollingtoft, A., Ulhoi, J.P., Madsen, A.H., \& Neergaard, H. (2003). Effect of financial factors on the performance of new venture companies in high tech and knowledge-intensive industries: an empirical study in Denmark. International Journal of Management, 20, 535-547.

Cassar, G. (2004). The financing of business start-ups. Journal of Business Venturing, 19, 261-283.

Coco, G. (2000). On the use of collateral. Journal of Economic Surveys, 14, 191-214.

Coleman, S., \& Cohn, R. (2000). Small firm use of financial leverage: Evidence from 1993 national survey of small business finance. Journal of Business Entrepreneurship, 12, 81-98.

Coulthard, M., \& Loos, J. (2007). Networking, the link in firm based entrepreneurial orientation (EO) performance model. [Online] Available: http://www.buseco.monash.edu.au/mgt/staff/coulthard.max.html (July 18, 2008).

Dahl, M.S., \& Sorenson, O. (2007). Home sweet Home? Social capital and location decisions. [Online] Available: http://www.druid.dk/fileadmin/images/dokumenter/sorenson.pdf (January 15, 2008).

Daniel, O., Masli, E., Rahman, K., \& Selvarajah, S.F. (2006). Determinant of capital structure in new ventures: evidence from Swedish longitudinal data. Journal of Development Entrepreneurship, 23, 204-231.

Demirguc-Kunt, A., Maksimovic, V., Beck, T., \& Laeven, L. (2006). The determinant of financing obstacles. International Journal of Money and Finance, 25, 932-952

FinMark Trust. (2006). Fin scope small business survey report. [Online] Available: http://www.finmarktrust.org.za (May 18, 2007).

Foxcroft, M., Wood, E., Kew, J., Herrington, M., \& Segal. N. (2002). Global Entrepreneurship Monitor, South African report. [Online] Available: http://www.gbs.nct.ac.za/gbswebb/userfiles/gemsouthafrica2000pdf (October 16, 2008).

Freeman, J.V., Walters, S.J., and Campbell, M.J. (2008). How to display data. (4 ${ }^{\text {th }}$ ed.). Oxford: Blackwell Publishing Inc.

Frelinghaus, A., Mostert, B., \& Firer, C. (2005). Capital structure and the firm's life stage. South African Journal of Business Management, 36, 9-18.

Gilbert, B.A. (2008). New venture performance: does location matters? [Online] Available: http://74.125.77.132/search/q=cache.DIZnExwD91 tmw.j.ftp/ftp.zew.de/pub (May 17, 2009).

Gitman, L.J. (2003). The Principles of Managerial Finance. ( $7^{\text {th }}$ ed.) New York: Pearson Education Inc.

Government Gazette of the Republic of South Africa. (2003). National Small Business Amendment Act. [Online] Available: http://www.info.gov.za/gazette/acts/2003/a26-03.pdf (June 20 2007).

Gree, A., \& Thurnik, C. (2003). Firm selection and industry evolution: the post country performance of new firm. Journal of Evolutionary Economics, 4, 243-264.

Hellriegel, D., Jackson, S.E., Slocum, J., Staude, G., Amos, T., Klopper, H.P., Louw, L., \& Oosthuizen, T. (2008). Management. ( $2^{\text {nd }}$ ed.). Oxford: Oxford University Press.

Herrington, M., \& Wood, E. (2003). Global Entrepreneurship Monitor, South African Report [Online] Available: http://www.gbs.nct.ac.za/gbswebb/userfiles/gemsouthafrica2000pdf (May 5, 2008).

Herrington, M., Kew, J., \& Kew, P. (2009). Global Entrepreneurship Monitor, South African report. [Online] Available: http://www.gbs.nct.ac.za/gbswebb/userfiles/gemsouthafrica2000pdf (October 15, 2009).

Hisrich, R.D., \& Drnovsek, M. (2002). Entrepreneurship and Small Business Research. Journal of Small Business and Enterprise Development, 9, 172-222. 
Kauffman Foundation. (2007). The capital structure decisions of new firms. [Online] Available: http://www.kauffman.org (November 20, 2008).

Kitindi, E.G., Magembe, B.A.S., \& Sethibe, A. (2007). Lending decision making and financial information: the usefulness of corporate annual reports to lender in Botswana. International Journal of Applied Economics and Finance, 1, 55-60.

Kortschak, T. (2007). The right amount of leverage. [Online] Available: http://www.summitpartners.com/uploadedfiles/news/newrelaese/recentnews (May 15, 2008).

Kraus, A., \& Litzenberger, R.H. (1973). A state-preference model of optimal financial leverage. Journal of Finance, 9, 911-922.

Lyles, M.A., Saxton, T., \& Watson, K. (2004). Venture Survival in a Transitional Economy. Journal of Management, 30, 351-375.

Maas, G., \& Herrington, M. (2006). Global entrepreneurship monitor South African report. [Online] Available: http://www.gemconsortium.org/document.aspx?id756 (June 6, 2008).

Martin, G., \& Staines, H. (2008). Managerial competencies in small firm. [Online] Available: http://www.emraldinsight.com/insight/viewcontentitem.do?contenttype. ( May17, 2009).

Modigliani, F., \& Miller, M.H. (1963). Corporate income taxes and the cost of capital: A correction. American Economic Review, 53, 433-444.

Modigliani, F., \& Miller, M.H. (1958). The cost of capital, corporation finance and the theory of investment. American Economic Review, 48, 261-295.

Myers, S.C. (1984). Capital structure puzzle. Journal of Finance, 39, 575-592.

Ngoc, T.B., Le,T., \& Nguyen,T.B. (2009). The impact of networking on bank financing: The case of small and medium enterprises in Vietnam. Entrepreneurship Theory and Practice, 33, 867-887.

Ntsika Enterprise Promotion Agency. (2002). State of small business development in South Africa annual review. [Online] Available: http://www.ntsika.org.za/ (April 19, 2007).

Owualah, S.1. (2002). SMEs borrowing constraints and banking relationship in Japan. Japan and the World Economy, 14, 87-100.

Peacock, R.W. (2004). Understanding small business: practice, theory and research. ( $6^{\text {th }}$ ed.) Adelaide: Scarman Publishing.

Pretorius, M., \& Shaw, G. (2004). Business plan in bank-decision making when financing new ventures in South Africa. South African Journal of Economics and Management Science, 7, 221-242.

Raosoft. (2008). Sample size calculation [Online] Available: http://www.ezsurvey.com/samplesize.html (May 17, 2008).

Reitan, B., \& Waago, S.J. (2002). Criteria used by private bank officer to evaluate new ventures: an empirical of gaps and shortcoming. [Online] Available: http://sbaer.uca.edu/research/icsb/1998pdf/111.pdf (January 11, 2007).

Richard, D. (2006). Equity gap? There is no such thing. [Online] Available: http://www.growingbusiness.co.uk (August 17, 2008).

Rungani, E. (2008). The determinants of the capital structure choices of SMEs in the Buffalo City Municipality. Unpublished Masters Dissertation, University of Fort Hare.

Scott, D.F. (1972). Evidence on the importance of financial structure. Journal on Financial Management, 1, 45-60.

Shane, S., \& Cable, D. (2002). Network ties, reputation and the financing of new ventures. Management Science, 48, 364-381.

Smallbone, D., \& Welter, F. (2001). The Distinctiveness of Entrepreneurship in Transition Economies. Small Business Economics, 16, 249-262.

Sogorb Mira, F. (2002). On the capital structure in small and medium enterprises: the Spanish case. [Online] Available: http://www.papers.ssrn. (July 17, 2008).

South African Presidency. (2008). The impact of crime on small business in South Africa. [Online] Available: http://www.info. gov.za/view/downloadfileaction?id85242 (May 15, 2009). 
South African Venture Capital Association. (2008). Venture capital funding. [Online] Available: http://www.savca.co.za/kpmgsurvey/default.aspn (May 20, 2009].

Statistics South Africa. (2009). Quarterly labour force survey. [Online] Available: http://www.statssa.gov.za/publication/find publication asp (November 18, 2009).

Stiglitz, J., \& Weiss, A. (1981). Credit rationing in markets with imperfect information. American Economic Review, 71, 393-410.

Von Broembsen, M., Wood, E., \& Herrington, M. (2005). Global entrepreneurship monitor South Africa report. [Online] Available: http://www.gsb.uct.ac.za/gsbwebb/userfiles/gem2005.pdf (October 17, 2007).

Wong, P.K., Ho, Y.P., \& Autio, E. (2005). Entrepreneurship, innovation and economic growth: Evidence from GEM data. Small Business Economics, 24, 335-350.

Table 1. Schedule of size standards for the definition of SMEs in South Africa

\begin{tabular}{|l|l|l|l|}
\hline Type of firm & No. of employees & Turnover & Balance sheet total \\
\hline Small & $1-49$ & Maximum R13m & Maximum R5m \\
\hline Medium & $50-200$ & Maximum R51m & Maximum R13m \\
\hline
\end{tabular}

Source: Government Gazette of the Republic of South Africa (2003).

Table 2. Logistic regression results for the determinants of credit approval

\begin{tabular}{|c|c|c|c|}
\hline Variable & Odd ratio & Confidence interval (95\%) & P-value \\
\hline Property & 7.04 & $2.99-9.66$ & 0.02 \\
\hline High education & 3.66 & $1.34-8.48$ & 0.04 \\
\hline Business education & 1.09 & $0.69-1.33$ & 0.22 \\
\hline Working experience & 1.72 & $0.82-5.21$ & 0.14 \\
\hline Related experience & 4.83 & $2.30-8.91$ & 0.04 \\
\hline Business plan & 6.62 & $3.11-10.02$ & 0.01 \\
\hline $\begin{array}{l}\text { Business plan produced with aid of } \\
\text { accountant/consultant }\end{array}$ & 1.45 & $0.61-7.19$ & 0.33 \\
\hline Professional association & 1.37 & $0.47-1.38$ & 0.27 \\
\hline \multicolumn{4}{|l|}{ Relationship with bank } \\
\hline No previous relationship (reference) & 1.00 & & \\
\hline Less than one year & 1.26 & $1.83-9.64$ & 0.01 \\
\hline More than one year but less than five & 2.47 & $1.02-4.17$ & 0.04 \\
\hline More than five years & 2.62 & \begin{tabular}{|l|}
$1.24-6.85$ \\
\end{tabular} & 0.04 \\
\hline Location (city or rural) & 3.65 & $1.92-8.60$ & 0.01 \\
\hline Insurance & 5.24 & $4.72-7.22$ & 0.04 \\
\hline Gender & 1.04 & $0.60-2.56$ & 0.19 \\
\hline Size of business & 3.79 & $1.88-6.01$ & 0.02 \\
\hline Legal status of business & 4.25 & $2.21-7.05$ & 0.04 \\
\hline \multicolumn{4}{|l|}{ Age } \\
\hline $21-30$ (reference) & 1.00 & & \\
\hline $31-40$ & 0.93 & $0.38-1.92$ & 0.29 \\
\hline $41-50$ & 1.09 & $0.52-2.58$ & 0.17 \\
\hline 51 above & 1.14 & $0.72-2.41$ & 0.22 \\
\hline \multicolumn{4}{|l|}{ Industry } \\
\hline Manufacturing (reference) & 1.00 & & \\
\hline Retail and wholesale & 0.88 & $0.46-1.87$ & 0.38 \\
\hline Catering and accommodation & 0.65 & $0.35-2.00$ & 0.69 \\
\hline Construction & 0.73 & $0.47-5.32$ & 0.35 \\
\hline Partner in business & 1.47 & $0.91-3.04$ & 0.44 \\
\hline Intercept & 0.21 & & 0.01 \\
\hline
\end{tabular}

Hosmer and Lemeshow test, $\mathrm{X} 2=9.86$ on 8 degrees of freedom, P-value $=0.2748$ 